Jurnal Pemikiran Sosiologi Volume 6 No. 2, Agustus 2019

\title{
Kritik Kekuasaan Mpu Tantular sebagai Ulayatisasi Ilmu Sosial Indonesia ${ }^{1}$
}

\section{Hartmantyo Pradigto Utomo² dan Purwanto. ${ }^{3}$}

\begin{abstract}
Abstraksi
Orientalisme dan kebergantungan akademis merupakan dua unsur yang menjangkiti ilmu sosial di Indonesia. Kedua unsur tersebut mengakibatkan kekosongan tradisi pemikiran ilmu sosial yang berasal dari Indonesia. Oleh karena itu, tulisan ini mengupayakan tradisi pemikiran alternatif melalui gagasan Mpu Tantular dalam Kakawin Sutasoma yang berasal dari zaman Kerajaan Majapahit. Pemikiran Mpu Tantular dipilih berdasarkan dua pertimbangan. Pertama belum terdapat penelitian ilmu sosial yang berfokus pada pemikiran zaman kerajaan Kedua relevansi pemikiran kritis yang terdapat di dalamnya. Penafsiran pemikiran Mpu Tantular dikerangkai dengan konsep Ulayatisasi Ilmu Sosial yang bertujuan untuk menghadirkan pusat ilmu pengetahuan yang baru. Metode penafsiran menggunakan hermeneutika untuk menghadirkan tafsir baru terhadap teks. Meletakkan pemikiran Mpu Tantular dalam tradisi ilmu sosial Indonesia dengan menghadirkan relevansi wacana kebergantungan akademis pada tradisi ilmu sosial Barat yang memuncak di zaman Orde Baru. Kebergantungan akademis dihadirkan melalui penerapan gagasan modernisme Amerika yang berbasis pada pemikiran Talcott Parsons. Ilmuwan sosial menerapkan gagasan modernisme Amerika yang bertujuan untuk melegitimasi kekuasaan ekonomi politik yang disertai dengan kekerasan rezim Orde Baru. Pada kondisi tersebutlah pemikiran Mpu Tantular mendapatkan relevansinya sebagai kajian awal guna menghadirkan tradisi pemikiran ilmu sosial Indonesia melalui gagasan kritik kekuasaan.
\end{abstract}

Kata kunci: Mpu Tantular, Ulayatisasi Pemikiran, Orientalisme, Kebergantungan Akademis, Kritik Kekuasaan, Ilmu Sosial Indonesia

\begin{abstract}
Orientalism and academic depedency are two elements that infects social science in Indonesia. Both of these elements resulted in the void of tradition of social scince thought originating from Indonesia. Therefore, this paper seeks the tradition of alternative thought through the idea of Mpu Tantular in Kakawin Sutasoma originating from the Majapahit Kingdom. Mpu Tantular's thought was choosen based on two consideration: firstly there is no social science research focus on thought from kingdom era dan secondly the relevance of critical thought contained in it. Interpretation of Mpu Tantular's thought is framed by the concept Indigenization of Social Science which aims to bring a new center of knowledge. The method of interpretation uses hermeneutics to present a new interpretation of the text. Putting the thought of Mpu Tantular in the traditon of Indonesian social science by presenting the discourse relevance of academic dependence on Western social science tradition that culminated in the New Order era. Academic dependence is presented through the application of the ideas of American modernism bas in Talcott Parsons's thought. Social scientist apply the idea of American modernism which aims to legitimize of political economic power accompained by the violence of the New Order regime. In this condition, Mpu Tantular's thought gained its relevance as a preliminary study to present the tradition of Indonesian social science thought through the idea of power criticism.
\end{abstract}

Keywords: Mpu Tantular, Indigenization Thought, Orientalism, Academic Depedency, Power Criticism, Indonesian Social Sciences.

\section{A. Latar Belakang}

Gagasan modernisme ilmu sosial Amerika

Serikat dalam tradisi pemikiran Talcott Parsons mulai diperkenalkan secara global di Negara Dunia
Ketiga sesudah Perang Dingin (Lele, 1993:49). Salah satu yang menjadi sasaran adalah negara di kawasan Asia Tenggara, salah satunya Indonesia, yang berposisi sebagai Negara Dunia Ketiga. Terdapat

\footnotetext{
${ }^{1}$ Untuk kutipan atau sitasi artikel ini: Utomo, Hartmantyo Pradigto dan Purwanto. 2019. "Kritik Kuasa Mpu Tantular sebagai Ulayatisasi Ilmu Sosial Indonesia." Jurnal Pemikiran Sosiologi Vol 6 (2): 150 - 168

2 Departemen Sosiologi, Fakultas Ilmu Sosial dan Ilmu Politik, Universitas Gadjah Mada. Kontak: tyoutomo94@gmail.com

${ }^{3}$ Departemen Sosiologi, Fakultas Ilmu Sosial dan Ilmu Politik, Universitas Gadjah Mada. Kontak: Posthumous (penulis wafat 7 Juli 2019, sebelum artikel dipublikasikan)
} 


\section{Jurnal Pemikiran Sosiologi Volume 6 No.2 2019 \\ Kritik Kuasa Mpu Tantular sebagai Ulayatisasi Ilmu Sosial Indonesia \\ Hartmantyo Pradigto Utomo dan Purwanto}

dua akibat dari penerapan gagasan modernisme Amerika Serikat: orientalisme dan kebergantungan akademis (Alatas, 2010:xiii). Orientalisme beroperasi pada wacana keilmuan sosial Amerika Serikat untuk menghegemoni cara berpikir Timur (Said, 1979:290). Sedangkan kebergantungan akademis berusaha menciptakan ketidaksetaraan keilmuan secara global di Negara Dunia Ketiga (Alatas, 2010:53).

Oleh karena itu, dibutuhkan usaha untuk lepas dari hegemoni dan ketidaksetaraan global dengan menyerukan diskursus alternatif bagi ilmu sosial di Indonesia. Salah satu ragam seruan diskursus alternatif adalah ulayatisasi ilmu sosial (Alatas, 2010:79). Ulayatisasi dalam ilmu sosial Indonesia dapat diawali melalui penafsiran ulang pemikiran Mpu Tantular dari zaman kerajaan yang hadir sebelum masa penjajahan Eropa. Penafsiran ulang tidak bertendensi mencari kemurnian asali dan otentik dari sebuah pemikiran, melainkan menjadi langkah awal menyusun tradisi keilmuan sosial yang mandiri dengan bersumber dari sejarah kontekstual (Alatas \& Sinha, 2017).

Usaha melepaskan ilmu sosial dari hegemoni dan ketidaksetaraan global sudah dilakukan dalam beberapa riset sebelumnya. Diawali dengan seruan penghadiran ilmu sosial Indonesia yang lebih kontekstual dan menyesuaikan kebutuhan negara Orde Baru (Kleden, Sikap Ilmiah dan Kritik Kebudayaan, 1988). Selanjutnya usaha untuk melacak secara genealogis keterlekatan ilmu sosial dengan kekuasaan yang beroperasi bermula sedari keilmuan Indologi zaman Hindia Belanda hingga puncak modernisme Amerika Serikat di zaman Orde Baru (Samuel, The Development of Sociology in
Indonesia: The Production of Knowledge, State Formation, and Economic Change, 1999). Kemudian dilanjutkan dengan usaha membongkar relasi kuasa dari perspektif ilmu sosial modernisme Amerika yang berada di balik pendefinisian Indonesia sebagai sebuah negara yang baru berkembang (Rahadianto \& Samuel, 2013). Hingga upaya merepresentasikan ilmu sosial Indonesia dalam kancah global melalui tradisi kerakyatan yang melekat pada citra khas Orde Baru (Fansuri, 2015).

Terdapat perbedaan mendasar dari penelitian ini dengan kajian literartur sebelumnya. Jika beberapa kajian sebelumnya berfokus pada diskursus keilmuan dan pemikiran disiplin sosiologi Indonesia modern, penelitian kali ini berupaya untuk menghadirkan gagasan kritik kekuasaan Mpu Tantular yang berada di luar pakem keilmuan sosiologi. Hal ini merupakan sebuah upaya merekonstruksi sejarah pemikiran sosiologi yang memiliki kedekatan dengan upaya yang dilakukan oleh Syed Farid Alatas dan Vineeta Sinha ketika membangun tradisi sosiologi alternatif dari gagasan pemikiran Asia (Alatas \& Sinha, 2017).

Berdasarkan penjelasan di atas, penelitian kali ini berupaya untuk menghadirkan gagasan kritik kekuasaan Mpu Tantular yang tertuang dalam Kakawin Sutasoma (Tantular, 2009). Gagasan tersebut didapatkan melalui hermeneutika pemikiran Mpu Tantular yang berasal dari zaman Kerajaan Majapahit untuk dikontekstualisasikan dalam lanskap keilmuan sosial dan kaitannya dengan kekuasaan politik di Indonesia. Pemikiran Mpu Tantular dipilih karena dilahirkan dari masa sebelum penjajahan yang belum dikaji sebagai sumber teoritis bagi keilmuan sosiologi Indonesia 


\section{Jurnal Pemikiran Sosiologi Volume 6 No.2 2019 \\ Kritik Kuasa Mpu Tantular sebagai Ulayatisasi Ilmu Sosial Indonesia \\ Hartmantyo Pradigto Utomo dan Purwanto}

hari ini. Kritik kekuasaan Mpu Tantular secara kontekstual dapat diterapkan bagi kritik rezim ilmu sosial Orde Baru yang dilahirkan dari pembunuhan massal dan melegitimasi eksploitasi ekonomi politik.

\section{B. Metode Penelitian}

Penafsiran ulang pemikiran Mpu Tantular dalam Kakawin Sutasoma dilakukan dengan menggunakan hermeneutika sebagai metode dalam tradisi pemikiran Paul Ricoeur. Hermeneutika dalam tradisi Paul Ricoeur berusaha melampaui tradisi penafsiran modern yang berupaya untuk mencari kesepahaman makna antara penafsir dengan penulis. Oleh karena itu, dimungkinkan untuk menghasilkan pemaknaan baru dari sebuah teks yang diiringi dengan proses refleksi subjektif yang ditautkan pada zaman yang menjadi latar kontekstual penafsir (Hardiman, 2015:241).

Proses penafsiran dilakukan menjadi dua tahapan hermeneutik Paul Ricoeur, tahapan metodologis dan ontologis. Pertama adalah tahap metodologis yang dibangun Paul Ricoeur dengan berpijak pada basis epoche fenomenologi Husserl. Tahapan ini dilakukan melalui dua langkah. Langkah pertama adalah dialetika pemahaman yang besifat penebakkan (versthen) menuju penjelasan yang berupa validasi (erklären). Langkah kedua adalah dialektika penjelasan yang bersifat eksplanatif (erklären) menuju pemahaman komprehensif (verstehen) (Ricoeur, 1976:75-88). Selanjutnya, tahapan kedua adalah tahap ontologis yang merupakan peristiwa bertemunya makna yang berada di dalam teks dengan dunia kontekstual penafsir yang menjadikan makna baru sebagai miliknya (apropriasi) (Ricoeur, 1976:92).

Pada langkah pertama dalam tahapan pertama, Kakawin Sutasoma dipahami sebagai proses penebakan secara tekstual yang menghasilkan asumsi konseptual awal. Kemudian asumsi konseptual tersebut dijelaskan melalui struktur objektif teks untuk memberikan validasi yang memungkinan sebagai sebuah pemaknaan (Ricoeur, 1976:76). Langkah kedua, asumsi konseptual dijelaskan secara eksplanatif berdasarkan struktur dan logika konseptual pada tingkatan semantik yang bertujuan untuk memahami konteks referensi asali teks (Ricoeur, 1976:81). Kemudian asumsi konseptual yang mengandung makna asali dipahami secara komprehensif dengan melalukan pemaknaan sesuai zaman kontekstual dan horizon pengetahuan penafsir yang menghasilkan pemaknaan baru. Gagasan kritik kekuasaan merupakan bentuk pemaknaan baru terhadap tafsir dari Kakawin Sutasoma.

Pada tahapan kedua yang merupakan tahap ontologis, pemakanaan baru tersebut direfleksikan sesuai dengan tujuan dan kebutuhan penafsiran (Haryatmoko, 2016:93). Pada tahapan ontologislah gagasan kritik kekuasaan dari teks Kakawin Sutasoma dapat menemui relevansinya dalam ilmu sosial Indonesia hari ini. Relevansi yang dipahami sebagai tujuan dan kebutuhan penafsir untuk melakukan kritik keilmuan sosial pada rezim Orde Baru. 
Jurnal Pemikiran Sosiologi Volume 6 No.2 2019

Kritik Kuasa Mpu Tantular sebagai Ulayatisasi Ilmu Sosial Indonesia

Hartmantyo Pradigto Utomo dan Purwanto

\section{Ulayatisasi Ilmu Sosial}

Ulayatisasi ilmu sosial merupakan konsep yang digagas oleh Syed Farid Alatas sebagai salah satu dari sekian konsep bagi seruan diskursus alternatif ilmu sosial Asia. Ulayatisasi ilmu sosial dipilih sebagai kerangka konseptual disebabkan berpijak dari kehadiran sejarah ulayat kontekstual (Alatas, 2010:83). Oleh sebab itu, terbuka kemungkinan bagi pemikiran Mpu Tantular dalam Kakawin Sutasoma yang berada di luar kanon untuk masuk dalam diskrusus ilmu sosial Indonesia.

Ulayatisasi ilmu sosial memiliki empat tujuan dalam upayanya menghadirkan diskursus pemikiran alternatif (Alatas, 2010:84). Pertama, upaya untuk membongkar dominasi dan selubung ideologis orientalisme dan eurosentrisme melalui beragam sumber pengetahuan ulayat. Kedua, upaya untuk menciptakan diskursus alternatif yang mendalam terkait persoalan metodologi dan epistemologi. Ketiga, memilah sumber pengetahuan ulayat secara selektif untuk tidak dengan ceroboh memutuskan hubungan diskursus alternatif dengan kaidah keilmuan sosial Barat. Keempat, menghadirkan cara pandang yang mendasar bahwasanya setiap kajian ilmu sosial merupakan sebuah proses ulayatisasi dari beragam sumber kontekstual.

Ulayatisasi ilmu sosial dapat dilakukan dengan empat cara (Alatas, 2010:82). Pertama, mendorong pemahaman konseptual secara mendalam. Kedua, menghadirkan relasi kedekatan diskursus alternatif dengan sumber kontekstualnya tanpa tendensi berlebih untuk menolak keseluruhan ilmu sosial Barat. Ketiga, melakukan pemetaan paradigma dan relasi ilmu sosial spada lanskap global untuk memahami kritik terhadap bias-bias universal. Keempat, menempatkan posisi pengetahuan lokal sebagai sumber kajian utama.

Terdapat dua orientasi diskursus alternatif untuk memberikan arah bagi ulayatisasi ilmu sosial. Pertama, oreintasi nativis yang bertendensi untuk mencari kemurnian ilmu pengetahuan lokal yang secara tendensius memutus hubungan dengan ilmu sosial Barat. Orientasi nativis tentu menjadi rawan oleh cara pandang auto-Orientalis disebabkan endapan pengetahuan selama ratusan tahun pada masa kolonial. Kedua, orientasi otonom yang mengacu pada kemandirian ilmuwan sosial dalam upaya menentukan permasalahan, pendekatan, dan metodologi pada kajian pengetahuan lokal. Orientasi otonom memungkinkan ilmuwan sosial di negara Dunia Ketiga untuk lepas dari belenggu ketergantungan akademis (Alatas, 2010:114).

Penelitian ini betujuan untuk pengerangkaan pemikiran Mpu Tantular dalam Kakawin Sutasoma dengan menggunakan ulayatisasi ilmu sosial berorientasi otonom. Disebabkan upayanya untuk menghadirkan sumber baru dalam kajian ilmu sosial yang berakar pada sejarah ulayat kontekstual yaitu zaman Kerajaan Majapahit. Sehingga pemikiran Mpu Tantular mampu mendorong kehadiran corak identik bagi diskursus alternatif bagi ilmu sosial Indonesia.

Usaha ulayatisasi ilmu sosial di Indonesia sebenarnya sudah lama terdengar semenjak masa Orde Baru. Usaha tersebut digagas oleh Ignas Kleden melalui Indigenisasi Ilmu-Ilmu Sosial Indonesia: Tanggapan Nasional atas Model Pembangunan dan Pembentukan Teori (Kleden, 1988:3). Ignas Kleden berangkat dari kritiknya terhadap kajian ilmu sosial 
Jurnal Pemikiran Sosiologi Volume 6 No.2 2019

Kritik Kuasa Mpu Tantular sebagai Ulayatisasi Ilmu Sosial Indonesia

Hartmantyo Pradigto Utomo dan Purwanto

zaman Orde Baru yang terlalu mengadopsi teoriteori Barat. Problem utama dari gagasan Ignas Kleden adalah perencanaan ulayatisasi yang berusaha dikonfigurasikan dengan kebutuhan kebijakan pemerintah Orde Baru dengan berpijak pada pertimbangan dua hal: yaitu efektivitas dan kualitas ilmiah. Ulayatisasi dalam cara pandang Ignas Kleden bertendensi untuk melalukakn penelitian yang dibiayai negara yang secara langsung justru menguatkan kontrol negara dalam ilmu sosial.

Oleh karena itu, gagasan ulayatisasi ilmu sosial yang diserukan oleh Syed Farid Alatas dipilih ketimbang menggunakan konsep dari Ignas Kleden. Terdapat beberapa faktor pemilihan tersebut. Pertama, Syed Farid Alatas memberikan gagasan yang lebih mendalam secara konseptual dan sistematis ketimbang Ignas Kleden yang masih sebatas ajakan yang abstrak. Kedua, gagasan Syed Farid Alatas memiliki relevansi yang lebih tepat dalam orientasi otonom bagi pemikiran $\mathrm{Mpu}$ Tantular ketimbang Ignas Kleden yang rawan pada orientasi nativis yang secara tendensius untuk memutus dialog dengan ilmu sosial Barat. Ketiga, kerawanan dari gagasan Ignas Kleden yang sekiranya mampu membuka kemungkinan hadirnya kembali kontrol otoritatif negara pada ilmu pengetahuan.

Penelitian ini berupaya untuk menggunakan kerangka konseptual ulayatisasi ilmu sosial yang ditunjang oleh metode hermeneutika dalam penafsiran teks Kakawain Sutasoma. Ulayatisasi ilmu sosial digunakan sebagai kerangka utama dalam mendudukkan cara pandang bagi pemikiran Mpu Tantular yang didasarkan pada konteks sejarah ulayat yaitu kondisi ekonomi politik dari rezim Hayam Wuruk sebagai masa puncak Kerajaan Majapahit. Hermeneutika dalam tradisi pemikiran Paul Ricoeur digunakan untuk memberikan penafisan tekstual dengan pemakanaan baru yang mendorong dialog kritis antara pemikiran $\mathrm{Mpu}$ Tantular sebagai diskursus alternatif dengan diskursus ilmu sosial Indonesia pada masa Orde Baru.

\section{Gagasan Kritik Kekuasaan Mpu Tantular sebagai Diskursus Alternatif}

Kakawin Sutasoma yang digunakan dalam penelitian ini menggunakan buku hasil terjemahan dari Dwi Woro Retno Mastuti dan Hastho Bramantyo yang dihadirkan dalam dua bahasa, yaitu bahasa Sanskerta dan Indonesia (Mastuti \& Bramantyo, 2009). Penyalinan naskah Kakawin Sutasoma yang tertua berupa lontar di Staatsbibliothek zu Berlin dengan kode Berlin SB Schoem tertanda tahun 1715 masehi dengan aksara Jawa Kuno. Penerjemahan pertama kali dalam bahasa Indonesia dilakukan oleh I Gusti Bagus Sugriwa pada tahun 1956 dalam bentuk stensilan 22 jilid yang diterbitkan oleh Pustaka Balimas yang tersimpan di perpustakaan Universitas Sanata Dharma, Yogyakarta.

Terjemahan mutakhir dalam bahasa Indonesia dilakukan dengan mempertahankan gaya bahasa dan model penulisan dari versi salinan tertua Kakawin Sutasoma. Gaya bahasa yang digunakan adalah bahasa khas zaman Kerajaan, yaitu bahasa Jawa Kuno dengan menggunakan serapan bahasa Sanskerta yang berasal dari tradisi India. Model penulisan menggunakan pola metrum persajakan 


\section{Jurnal Pemikiran Sosiologi Volume 6 No.2 2019 \\ Kritik Kuasa Mpu Tantular sebagai Ulayatisasi Ilmu Sosial Indonesia \\ Hartmantyo Pradigto Utomo dan Purwanto}

yang terbagi dalam bait-bait canto berpola yang merupakan corak dari persajakan Sanskerta. Kakawin Sutasoma terdiri dari canto I hingga CXLVIII.

Penelitian ini menemukan gagasan kritik kekuasaan Mpu Tantular yang relevan bagi diskursus alternatif ilmu sosial Indonesia dari buku terjemahan di atas. Gagasan kritik kekuasaan dipahami sebagai sebuah penafsiran baru yang berbeda dari kajian sebelumnya yang berhenti pada upaya menegok relasi kontekstual antara teks dengan wayang, relasi agama Hindu dan Buddha, serta kisah Borobudur (Santoso, 1975). Juga penafsiran populer yang disematkan pada Kakawin Sutasoma terbatas pada penggalan kata Bhinneka Tungga Ika (Supomo, 2000). Penafisran populer tersebut justru menyederhanakan lanskap konseptual dari Kakawin Sutasoma yang terbatas pada citra pluralisme yang digunakan sebagai landasan negara. Oleh karena itu, gagasan kritik kekuasaan sebagai sebuah tafsir baru juga berupaya untuk menyangkal kedangkalan-kedangkalan historis yang sering dilakukan demi melegitimasi kebutuhan negara.

Gagasan kritik kekuasaan disusun sesuai dengan proses hermeneutika sebagai metode dalam pemikiran Paul Ricoeur. Hermeneutika diawali dengan langkah pertama dalam tahapan metodologis yaitu proses penebakan kritik kekuasaan sebagai asumsi konseptual awal. Penebakan tersebut berpijak pada posisi subjek Pangeran Sutasoma sebagai putra Kerajaan Hastina dalam konteks Zaman Kaliyuga (canto 3.1). Secara etimologi Kaliyuga terdiri dari Kali yang 'berarti waktu yang kacau' dan Yuga yang berarti 'dunia'
(Zoetmolder \& Robson, 2006:437). Mpu Tantular mengonsepkan Zaman Kaliyiyuga sebagai rezim dominasi Kerjaan Ratnakanda yang dipimpin oleh makhluk raksasa bernama Dewa Kala dan Raja Purusada yang bertujuan memporak-porandakan dunia manusia (canto 1.7).

Kritik kekuasaan sebagai asumsi konseptual awal kemudian divalidasi dengan berpijak pada struktur objektif teks. Pada proses validasi didapatkan dua fase besar yang menjadi landasan narasi kritik kekuasaan. Pertama, fase penolakan kekuasaan dari Pangeran Sutasoma yang memilih untuk meninggalkan istana demi menetapkan diri pada upaya Bhoddisatwa dan tidak peduli terhadap kekacuan Zaman Kaliyuga (canto 4.9-39.5). Fase tersebut mengupayakan gagasan keterlepasan subjek dari kondisi objektif dunia untuk memilih jalan kesunyian yang abadi demi menggapai nirwana. Kedua, fase penerimaan kekuasaan ketika Pangeran Sutasoma memutuskan kembali menuju Kerajaan Hastina dan menerima takhta sebagai raja untuk mengakhiri Zaman Kaliyuga. Posisi sebagai raja ditempatkan sebagai pemantik bagi perlawanan kolektif terhadap usaha-usaha penghancuran dunia manusia oleh Kerajaan Ratnakanda (canto 54.7148.4).

Peralihan dari fase penolakan kekuasaan menuju penerimaan kekuasaan terjadi dengan penekanan hakikat subjek yang terpapar oleh kekuasaan dan ilmu pengetahuan. Peralihan dituliskan secara metaforik ketika Pangeran Sutasoma hampir mendapati perwujudan sempurnanya sebagai Sri Wairocana. Namun, kedatangan Dewa Indra mengupayakan Pangeran Sutasoma untuk tetap berada di dunia demi 


\section{Jurnal Pemikiran Sosiologi Volume 6 No.2 2019 \\ Kritik Kuasa Mpu Tantular sebagai Ulayatisasi Ilmu Sosial Indonesia \\ Hartmantyo Pradigto Utomo dan Purwanto}

menantang upaya penghancuran oleh Kerajanaan

Ratnakanda. Hal ini didasari oleh hakikat bahwa

Pangeran Sutasoma dilahirkan dengan tujuan untuk mengehentikan kekerasan para rezim Raja Purusada (canto 54.11).

Langkah kedua dalam tahapan metodologis adalah melakukan eksplanasi dari gagasan kritik kekuasaan yang bertujuan untuk menghadirkan dialog antara penafsiran baru dan konteks asali sebagai referensi ketika teks dituliskan. Kakawin Sutasoma diperkirakan mulai ditulis pada 1367 dan selesai pada 1389. Konteks asali dari Mpu Tantular merujuk pada canto 148.4 dengan menyebut Tuanku Sri Ranamanggala yang merupakan gelar dari Raja Hayam Wuruk sebagai penutup kakawin. Sesuai dengan perkiraan penulisan dan penyebutan gelar raja, gagasan kritik kekuasaan memang ditujukan sebagai kritik terhadap rezim Hayam Wuruk sebagai referensi asali teks.

Kritik kekuasaan sebagai referensi asali diposisikan dengan menyandingkan Zaman Kaliyuga dengan Zaman Puncak Kerajaan Majapahit di bawah pimpinan Hayam Wuruk. Raksasa dalam narasi Kakawin Sutasoma diposisikan sebagai metafora kedaulatan mutlak dari kepemimpinan Hayam Wuruk. Kondisi porak-poranda Zaman Kaliyuga merupakan metafora bagi ekspansi ekonomi politik dan militer dari Kerajaan Majapahit untuk menaklukkan kerajaan-kerajaan lainnya yang terbantang dari Pulau Jawa hingga menuju luar Nusantara. Ekspansi dilaksanakan sedari tahun 1300-an dan memuncak pada Raja Hayam Wuruk di akhir abad 14. Sebuah rentang waktu yang menjadi puncak kerajaan Nusantara sebagai episentrum perdagangan dunia (Lombard, 1996:46). Puncak kejayaan yang dikenal melalui salah satu simbol puncak dari ekspansi yang menjadi momentum sejarah paling sering diagung-agungkan, ialah Sumpah Hamukti Palapa oleh Patih Gadjah Mada (Yamin, 1975).

Ekspansi ekonomi politik dengan sifat yang militeristik dilakukan Kerajaan Majapahit dengan dua cara, yaitu persekutuan dan penaklukan (Lombard, 1996:103). Persektuan memiliki kecenderungan kerja sama yang berguna untuk menguatkan basis kapital dari Kerajaan Majapahit. Selanjutnya penaklukan cenderung menguasai dalam arti melakukan peperangan untuk memposisikan kerajaan lawan berada di bawah kendali Kerajaan Majapahit seutuhnya. Melalui ekspansi tersebut luas wilayah Kerajaan Majapahit terbentang dari Semenanjung Melayu hingga Timur Kepulauan.

Proses terakhir dari tahapan metodologis adalah dengan memberikan pemahaman komprehensif terhadap hasil eksplanasi gagasan kritik kekuasaan yang sudah dipahami konteks asaliya. Referensi metaforik dari Mpu Tantular dipahami secara komprehensif melalui kerangka keilmuan modern, yaitu dipahami dengan membasiskan pada susunan dasar ilmu pengetahuan dari ontologi, epistemologi, dan aksiologi. Basis susunan ilmu pengetahuan modern dihadirkan guna memberi jembatan untuk mendudukkan pemikiran Mpu Tantular dalam kaidah keilmuan sosial.

Basis ontologi Mpu Tantular dihadirkan dengan menjangkarkan pada referensi konteks asali Kakawin Sutasoma, yaitu aliran Buddha Mahayana yang berpusat pada ontologi Siddharta Gautama 


\section{Jurnal Pemikiran Sosiologi Volume 6 No.2 2019 \\ Kritik Kuasa Mpu Tantular sebagai Ulayatisasi Ilmu Sosial Indonesia \\ Hartmantyo Pradigto Utomo dan Purwanto}

(Kalupahana, 1986:98). Basis ontologi kritik kekuasaan tersebut adalah kausalitas: sebuah hukum sebab-akibat yang menjadi hakekat dari kehadiran seluruh fenomena dan benda duniawi. Ontologi kausalitas memiliki empat ciri khas: objektivitas, nesesitas, invariabilitas, dan kondisional (Kalupahana, 1986:24).

Ciri objektivitas berupaya untuk memahami kondisi-kondisi kehadiran dari sebuah benda atau peristiwa. Ciri nesesitas dan invariabilitas menyatakan latar belakang kehadiran benda atau peristiwa tidak akan pernah jauh dari sebab yang memantik kehadirannya. Sedangkan kondisional merupakan ciri paling krusial, yaitu hubungan sebab-akibat memiliki latar belakang tak akan pernah tunggal dan selalu terkait secara kontekstual. Keempat ciri tersebut digunakan untuk memahami hakikat kehadiran yang bersala dari berbagai keragaman latar belakang dan tak pernah tunggal.

Ontologi yang dihadirkan bagi Mpu Tantular merupakan orientasi yang berpijak pada peleburan dua golongan dominan substansialis dan naturalis. Golongan substansialis berupaya untuk memahami sebab-akibat benda atau peristiwa secara rasionalitas subjektifnya, sedangkan golongan naturalis berupaya untuk memahami hakikat sebabakibat benda dan peristiwa berdasarkan dirinya. Mpu Tantular, dengan meminjam Siddharta Gautama, meletakkan basis ontologi kausalitas pada keduanya, yaitu peleburan tafsir subjektif bersama kondisi-kondisi objektif sebagaii hakikat dari benda atau peristiwa..

Konsekuensi ontologi dari kausalitas yang diterapkan oleh $\mathrm{Mpu}$ Tantular adalah basis epistemologi yang turut berdiri di atas pemaknaan subjektif dan kondisi objektif. Mpu Tantular membasiskan epistemologi kritik kekuasaan pada konsep Indria yang diperkenalkan Siddharta yang meleburkan epistemologi golongan substansialis subjektif dengan naturalis objektif. Epistemologi Indria berpijak pada dua fungsinya dalam melakukan susunan ilmu pengetahuan, yaitu sensori dan ekstrasensori (Kalupahana, 1986:16). Sensori merupakan kepekaan terhadap kondisi objektif melalui tubuh biologis seperti mata, telinga, hidung, lidah, dan kulit sebagai konteks memahami batasanbatasan kebendaan dari sebuah peristiwa. Sedangkan ekstrasensori merupakan upaya pemahaman yang bertujuan untuk menembus makna dibalik batasan kebendaan dari peristiwa. Ekstrasensori dihadirkan dalam bentuk retrokognisi dan psikonesis dari pengalamanpengalaman subjektif.

Basis aksiologi Mpu Tantular berpijak pada dua hal. Pertama, narasi peralihan fase penolakan kekuasaan menuju penerimaan kekuasaan Sutasoma sebagai Raja Hastina. Kedua, pemahaman metaforik dari Zaman Kaliyuga bagi kekuasaan rezim Raja Hayam Wuruk. Mpu Tantular berusaha menautkan pemahaman subjektif (teoritik) dengan praktik yang bertujuan untuk melakukan intervensi pada kondisi-kondisi objektif dari realitas. Subjek dalam basis ontologi diposisikan sebagai basis utama dari aksiologi yang berupaya untuk melakukan intervensi kondisi objektif. Oleh karena itu, kritik ditempatkan sebagai sebuah aksiologi yang didasarkan pada pemahaman menganai tolok ukur kontekstual antara yang "baik" dan "buruk" 


\section{Jurnal Pemikiran Sosiologi Volume 6 No.2 2019 \\ Kritik Kuasa Mpu Tantular sebagai Ulayatisasi Ilmu Sosial Indonesia \\ Hartmantyo Pradigto Utomo dan Purwanto}

bagi kondisi-kondisi kemanusiaan dalam cara pandang Buddha Mahayana (Kalupahana, 1986:49).

Kritik sebagai aksiologi ditempatkan secara kontekstual oleh Mpu Tantular untuk menafsir kondisi objektif dari realitas rezim Raja Hayam Wuruk yang tidak berkesesuaian dengan ajaran Buddha Mahayana. Keseluruhan kritik tentu berpijak dari proses reflektif terhadap ontologi kausalitas yang mencurigai ragam penyebab kedaulatan mutlak dari rezim. Berikut proses epistemologi Indria yang berusaha untuk menembus batas-batas peristiwa ekspansi ekonomi politik. Kritik dilancarkan pada kekuasaan yang 'buruk' dan tidak tepat karena terjadi pembunuhan manusia demi ekspansi ekonomi politik melalui proses peperangan yang bersifat militeristik dengan mengorbankan banyak manusia sebagai biaya imperatif dari kekuasaan.

Tahapan berikutnya dari prosedur hermeneutika Paul Ricoeur adalah tahapan ontologis. Merupakan tahapan yang melandasi pertemuan dialogis antara gagasan kritik kekuasaan Mpu Tantular dengan horizon penafsir yang disesuaikan dengan kebutuhan penafsiran sebagai tujuan utama. Pertemuan dialogis tersebut digunakan untuk menjadikan pembaruan makna sebagai tafsir subjektif bagi penafsir. Sekaligus juga melipat jarak kontekstual antara Mpu Tantular pada masa Kerajaan Majapahit sebagai sumber ulayatisasi dengan ilmu sosial Indonesia sebagai tujuan penafsiran.

Mendudukan gagasan kritik kekuasaan Mpu Tantular sebagai diskursus alternatif ilmu sosial Indonesia diawali dengan penelusuran sejarah terlebih dahulu. Penelusuran sejarah ilmu sosial bertujuan untuk mengetahui ketergantungan ilmu sosial Indonesia dengan perspektif teoritis Barat. Ketergantungan yang menghasilkan cara pandang orientalisme dan beban ketergantungan akademis. Pada upaya tersebutlah gagasan kritik kekuasaan Mpu Tantular dihadirkan sebagai salah satu bentuk penerapan alternatif pemikiran yang berasal dari keragaman sumber ulayat kontekstual.

Ilmu sosial pertama kali hadir pada zaman kolonialisme Hindia Belanda melalui inisiasi Thomas Stamford Raffles pada awal abad 19 dalam bukunya History of Java yang berisi kajian sosial penduduk Hindia Belanda. Estafet keilmuan dilanjutkan dengan pendirian pusat studi di Leiden pada 1851 yang bernama KITLV ( Royal Institute of Linguistics, Geography and Etnology of the Netherlands Indies/Koninklijk Instituut Vor Tall-, Land- En Volkenkunde Van Nederlandsch- Indie) (Samuel, 2010:12). Pada pusat studi tersebutlah dihadirkan disiplin ilmu sosial bernama Indologie untuk menjadi fondasi bagi kebijakan pemerintahan kolonial. Indologie dirancang untuk memahami keadaan masyarakat Hindia Belanda dari cara pandang pencerahan Eropa. Oleh karena itu, Indologie beranggotakan ahli-ahli yang memiliki pengalaman panjang di Hindia Belanda.

Fondasi pencerahan Eropa semakin kuat ketika didenggungkannya gerakan Politik Etis melalui artikel van Deventer yang berjudul een Eereschuld (Dhakidae, 2003:68). Salah satu programnya tentu mambalas hutang budi dari eksploitasi di Hindia Belanda dengan program pendidikan. Imbas dari program tersebut adalah kedatangan dan bercokolnya ilmuwan Eropa di Hindia Belanda. Salah dua di antaranya adalah 


\section{Jurnal Pemikiran Sosiologi Volume 6 No.2 2019 \\ Kritik Kuasa Mpu Tantular sebagai Ulayatisasi Ilmu Sosial Indonesia \\ Hartmantyo Pradigto Utomo dan Purwanto}

Snouck Hurgronje dan J. H. Boeke. Snouck Hurgronje dikenal dengan kajian kebijakan Islam dan dinamika masyarakat Aceh (Hurgronje, 1994). Sedangkan J. H. Boeke populer dengan konsep dualisme ekonomi (Boeke, 1983). Keduanya menghasilkan cara pandang berupa stigma pembangkang dan terbelakang bagi masyarakat ulayat Hindia Belanda. Penelitian keduanya dapat digunakan secara politis sebagai landasan penerapan kebijakan di masa akhir kolonialisme Hindia Belanda.

Kemerdekaan Indonesia turut memalingkan rezim ilmu sosial sedari Indologie menuju modernisme Amerika Serikat. Konteks besar dihadirkannya gagasan modernisme adalah upaya Amerika untuk membendung laju Komunisme dan gagasan Marxisme di Asia Tenggara pada masa Perang Dingin. Dua upaya dihadirkan oleh Amerika untuk menancapkan dominasinya di Indonesia. Pertama, mendirikan tiga pusat studi Indonesia di tiga universitas: Cornell University, Yale University dan Massachusetts Institue of Technology (Samuel, 2010:81). Kedua, memberikan beasiswa pendidikan tinggi bagi ilmuwan muda Indonesia untuk bersekolah di tiga perguruan tinggi tersebut melalui The Formington Scheme (Dhakidae, 2003:330).

Paradigma teoritik yang diperkenalkan dari modernisme Amerika Serikat adalah gagasan fungsionalisme Talcott Parsons (Samuel, 2010:67). Fungsionalisme diperkenalkan secara lebih dominan oleh para sosiolog generasi awal sepulang dari kuliah di Amerika ketika Indonesia mulai memasuki era Orde Baru. Dua nama yang menjadi fondasi awal adalah Soerjono Soekanto dan Selo Soemardjan. Paradigma fungsionalisme menjadi dekat dengan kekuasaan ketika ciri paradigma yang berusaha mencari keseimbangan sistemik tersebut begayung sambut dengan ideologi modernisme Orde Baru yang dikenal dengan Pembangunanisme (Developmantalism) (Heryanto, 2006:71).

Puncak dari kedekatan paradigma fungsionalisme ilmu sosial dengan kekuasaan Orde Baru terjadi dengan tren birokratisasi ilmu sosial. Birokratisasi keilmuan dirancang melalui kehadiran lembaga-lembaga yang bertugas untuk melegitimasi kebijakan negara otoritarian untuk melakukan kontrol dan pengawasan yang ketat terhadap ilmu sosial. Dua lembaga tersebut adalah HIPIIS (Himpunan Indonesia untuk Pengembangan IlmuIlmu Sosial) dan penggantian MIPI menjadi LIPI (Lembaga Ilmu Pengetahuan Indonesia (Samuel, 2010:138). Peran lembaga tersebut dalam melegitimasi kebijakan negara adalah dengan melakukan kanonisasi paradigma fungsionalisme melalui beberapa ciri keilmuannya: objektif, universal, dan netral.

Determinasi rezim kekuasaan Orde Baru kepada ilmu sosial sebagai puncak kebergantungan akademis tersebutlah yang berusaha dikritik dengan menggunakan gagasan kritik kekuasaan $\mathrm{Mpu}$ Tantular. Gagasan Mpu Tantular yang berasal dari abad ke-14 coba dibawa untuk membaca realitas sosial Orde Baru diawali dengan mendudukan modus ontologi kausalitas yang berusaha mencari hubungan sebab dan akibat dari sebuah realitas sosial Orde Baru sebagai sebuah peristiwa objektif yang memiliki hukum sebab dan akibat. Realitas sosial Orde Baru melalui ciri nesesitas dan invariabilitas hadir melalui pemahaman wacana stabilisasi dan ketertiban yang terkait erat dengan latar belakang kehadirannya. Latar belakang 


\section{Jurnal Pemikiran Sosiologi Volume 6 No.2 2019 \\ Kritik Kuasa Mpu Tantular sebagai Ulayatisasi Ilmu Sosial Indonesia \\ Hartmantyo Pradigto Utomo dan Purwanto}

tersebut dapat dipahami melalui ciri kondisional dari Orde Baru yang lahir berkat kekuasaan ekonomi politik yang berlandaskan para sifat militeristik dan legitimasi keilmuan sosial modernisme Amerika dalam konteks Perang Dingin di Asia Tenggara.

Kekuasaan ekonomi politik yang bersifat militeristik secara ontologis dapat dipahami sebagai pemaknaan metaforik baru. Jika referensi konteks asali dari Kakawin Sutasoma adalah rezim Raja Hayam Wuruk, maka pemaknaan baru ditujukan bagi rezim otoritarian Orde Baru. Sebuah rezim yang hakikatnya dilahirkan dari pembantaian massal pada tahun 1965-1966 yang berupaya untuk memperluas ekonomi kapital dan dominasi politik yang berhaluan pada bentuk-bentuk kapitalisme birokratis. Perubahan besar terjadi setalah tahun 1965 yang ditandai dengan mulai masuknya paham pasar bebas yang menjadi ladang kedekatan militer dengan perusahaan swasta.

Konsekuensi epistemologis dengan menggunakan gagasan Mpu Tantular adalah dengan meletakkan realitas sosial Orde Baru diawali dengan pemahaman pada kondisi objektifnya sebagai peristiwa melalui indria sensori. Rezim Orde Baru mulai menampakkan gejala inderawi terkuatnya yang ditandai dengan Undang-Undang Penanaman Modal Asing (PMA) No. 1 Januari 1967 dan UndangUndang Penanaman Modal Dalam Negeri (PMDN) Juli 1968. Kebijakan tersebut diimplementasikan lewat program Pelita (Pembangunan Lima Tahun) oleh pemerintah Orde Baru. Sebuah kebijakan ekonomi liberal dengan berlandaskan semangat laissez-faire yang dijalankan dengan kekuatan negara otoriter dalam negeri yang turut dirangkap dengan ketergantungan pada ketentuan IMF, IBRD (International Bank for Reconstruction and Development/World Bank), dan IGGI (InterGovernmental Group on Indonesia) (Robinson, 2012:104).

Proses berikutnya adalah pemahaman yang berupaya menembus batas-batas indria sensori menuju ekstrasensori. Pada posisi tersebutlah ilmu sosial Indonesia diposisikan sebagai faktor ekstrasensori yang tidak secara langsung hadir dipermukaan sebagai kondisi objektif Orde Baru. Posisi tersebutlah yang memampukan ilmu sosial untuk mengupayakan legitimasi terhadap kebijakan ekonomi politik yang bersifat militeristik sekaligus meredam kritik dan merekayasa hakikat kekerasan ekonomi politik Orde Baru pada tahun 1965-1966 menjadi suatu yang wajar dan perlu dilakukan demi stabilitas dan ketertiban negara.

Proses legitimasi ilmu sosial pada rezim Orde Baru diapat dipahai melalui paradigmana fungsionalisme Talcott dengan batasan-batasan penerapannya di Indonesia masa Orde Baru. Terutama sekali perkenalan pemikiran Talcott Parsons yang tidak lepas dari bias cara pandang Amerika dalam menyebarkan perspektif Modernisme yang berguna menyokong gagasan Pembangunanisme Orde Baru. Terlihat jelas di beberapa tulisan para ilmuwan sosial pada dekade 80an. Seperti Taufik Abdullah dalam Ilmu Sosial dan Peranannya di Indonesia (1983) dan Pelaksanaan Masa Lampau dan Arah Masa Depan; Negara dan Ilmu Sosial di Indonesia (1997). Soediono M.P Tjondronegoro dengan judul Penelitian Ilmu Sosial dan Penentu Kebijakan (1983), Selo Soemardjan yang menulis tentang Ilmu itu Netral dan Ilmuwan 


\section{Jurnal Pemikiran Sosiologi Volume 6 No.2 2019 \\ Kritik Kuasa Mpu Tantular sebagai Ulayatisasi Ilmu Sosial Indonesia \\ Hartmantyo Pradigto Utomo dan Purwanto}

Harus Objektif (1984). Juga tulisan dari P.N Usman

Tampubolon yang berjudul Matematisasi Ilmu-IImu

Sosial . Selain itu Soedjatmoko juga menulis tentang

Etik dalam Perumusan Strategi Penelitian Ilmu-ilmu

Sosial (1983), dan Ignas Kleden dalam Ilmu Sosial di

Indonesia; Tindakan dan Refleksi dalam Perspektif Asia Tenggara (1997).

Perkenalan pemikiran Talcott Parsons ditelaah lewat pemikiran tiga ilmuwan sosial yang menjadi kanon pada jaman Orde Baru: Selo Soemardjan, Soerjono Soekanto, dan Nasikun. Selo Soemardjan dipilih tidak lain dikarenakan cara berpikir sosiologis awal di Indonesia tidak lepas dari perannya dalam melembagakan sosiologi sebagai disiplin keilmuwan lewat pendirian jurusan sosiologi di Universitas Indonesia sehingga dianugerahi sebagai Bapak Sosiologi Indonesia (Riyanto, 2011). Soerdjono Soekanto dipilih berdasarkan pengaruh besar dari karyanya yang merupakan kumpulan catatan perkuliahan dari Selo Soemardjan sekaligus menjadi kanon sosiologi di Indonesia, yaitu Sosiologi Suatu Pengantar (1982). Selain itu, Soerjono Soekanto juga dipilih berdasarkan karyanya bersama Ratih Lestari yang menjelaskan perspektif fungsionalisme dari beberapa tokoh utamanya guna memetakan perspektif tersebut dalam perkembangan sosiologi (1988). Ketiga, Nasikun yang menggunakan perspektif fungsionalisme untuk menjelaskan sistem sosial di Indonesia pada masa Orde Baru (2015).

Definisi disiplin sosiologi dari Selo Soemardjan memiliki kedekatan dengan Talcott Parsons sebagai ilmu yang memperlajari struktur sosial dan proses-proses sosial, dan perubahan- perubahan sosial (Riyanto, 2011:160). Selo Soemardjan juga memberikan definisi struktur sosial sebagai jalinan dari berbagai unsur-unsur sosial yang terdapat di masyarakat, seperti norma sosial, lembaga sosial, dan lapisan sosial. Jalinan antar unsur sosial tersebut memunculkan sifat dan pengaruhnya pada masyarakat yang disebut dengan proses sosial.

Soerjono Soekanto memberikan tujuh sifat dari hakikat sosiologi sebagai disiplin ilmu pengetahuan (1982:18-21). Pertama, penegasan bahwa sosiologi merupakan ilmu sosial yang bertugas menangkap gejala-gejala sosial dan jelas berbeda dengan ilmu alam yang berusaha menangkap gejala fisik alamiah. Kedua, sosiologi adalah disiplin ilmu kategoris yang bertujuan untuk melakukan penilaian terhadap gejala sosial di masyarakat dan memberikan porsi sesuai dengan konsep dan kategori. Ketiga, sosiologi merupakan ilmu murni yang berusaha mencari abstraksi dan memperdalam analisa dari setiap gejala-gejala sosial. Keempat, pencarian pada abstraksi dan pendalam analisa menegaskan bahwa sosiologi adalah disiplin ilmu abstrak dan bukan ilmu pengetahuan kongkret. Kelima, sosiologi bertujuan untuk menghasilkan pengertian-pengertian dan pola-pola umum. Keenam, sosiologi merupakan ilmu pengetahuan yang empiris dan rasional. Ketujuh, sosiologi adalah disiplin keilmuwan yang bersifat umum untuk memahami gejala sosial secara universal.

Ketujuh hakikat tersebut membawa sosiologi sebagai disiplin ilmu yang didefinisikan Soerjono Soekanto dalam empat ciri (1982:13). Pertama, sosiologi sebagai disiplin keilmuwan yang 


\section{Jurnal Pemikiran Sosiologi Volume 6 No.2 2019 \\ Kritik Kuasa Mpu Tantular sebagai Ulayatisasi Ilmu Sosial Indonesia \\ Hartmantyo Pradigto Utomo dan Purwanto}

bersifat empiris yang berarti menjadikan realitas sebagai basis utama. Kedua, sosiologi bersifat teoritis yang menjadikan sebagai ilmu pengetahuan yang bertujuan untuk menyusun abstraksi hasil dari pemahaman realitas. Ketiga, sosiologi bersifat kumulatif yang berusaha untuk memperbarui dan memperbaiki teori-teori lama. Keempat, sosiologi bersifat nonetis yang berusaha untuk tidak meributkan penilaian baik dan buruk, melainkan memahami realitas sedalam mungkin.

Soerjono Soekanto dan Ratih Lestari menggunakan definisi dan hakikat disiplin sosiologi sebagai landasan dalam menentukan basis teori yang dibalut dengan klaim terhadap konsep Leviathan dari Thomas Hobbes (1988:10). Soerjono Soekanto dan Ratih Lestari mendekatkan konsep Leviathan yang menyatakan bahwa manusia hidup dalam ketakutan yang diakibatkan oleh kekerasan dengan kebutuhan untuk mencari jalan keluar melalui ketertiban sebagai keadaan alamiah manusia yang dapat diciptakan dengan teori sosiologi yang secara tersirat berbasis pada pemikiran Talcott Parsons. Bahkan menyatakan kecenderungan umum para sosiolog untuk bersetuju dengan konsep Thomas Hobbes tersebut.

Definisi, hakikat, dan klaim terhadap Thomas Hobbes pada disiplin sosiologi digunakan sebagai teori sosiologi dengan tiga tujuan pokok (1988:10). Pertama menyusun klasifikasi untuk menciptakan penggolongan dari berbagai gejala sosial. Kedua untuk menjelaskan faktor-faktor yang menjadi penyebab munculnya gejala sosial sekaligus menciptakan prediksi. Ketiga untuk menyajikan pemahaman mengapa dan bagaimana gejala sosial tertentu terjadi. Keseluruhan tujuan tersebut diturunkan Soerjono Soekanto melalui empat unsur yang menjadi basis dari teori: konsep, variabel, pernyataan, dan format.

Konsep dan variabel lebih mengacu pada berbagai macam interaksi, kaidah, peranan, kedudukan, sosialisasi, kekuasaan, dan relasi dari setiap kelompok sosial. Menilik pada definisi dan hakikat sosiologi yang menjadikan realitas sebagai telaah utama, konsep menempati unsur terpenting dari pembentukan teori. Dikarenakan konsep berusaha untuk menangkap abstraksi sebagai pemahaman dari relasi dan pola yang terbentuk dari setiap konsep. Pernyataan dalam bahasa Soerjono Soekanto adalah definisi operasional yang berguna untuk menghubungkan antar konsep abstrak dan merumuskan indikator bagi penentuan klasifikasi. Berikutnya format yang dalam usaha perumusan teori bertujuan sebagai penentuan kelengkapan dan prasyarat terkait konsep abstrak yang menunjang klasifikasi, kemudahan dalam melakukan identifikasi terhadap realitas sosial, dan faktorfaktor yang menyebabkan sebuah fenomena terjadi.

Secara singkat Soerjono Soekanto dan Ratih Lestari berusaha untuk melegitimasi prasyaratprasyarat ilmiah untuk dibawanya pada posisi kebutuhan masyarakat terhadap ketertiban dan kestabilan. Fungsinalisme Talcott Parsons dihadirkan sebagai paradigma teoritis yang menempatkan masyarakat sebagai realitas sosial yang menunjukan gejala ketakutan dan disiplin sosiologi yang sudah didefinisikan sedemikian rupa hadir sebagai pemecah masalah untuk memberikan sebuah bentuk-bentuk ketertiban.

Definisi sosiologi dalam perspektif fungsionalisme dibagi oleh Nasikun ke dalam tujuh 


\section{Jurnal Pemikiran Sosiologi Volume 6 No.2 2019 \\ Kritik Kuasa Mpu Tantular sebagai Ulayatisasi Ilmu Sosial Indonesia \\ Hartmantyo Pradigto Utomo dan Purwanto}

anggapan dasar yang berguna untuk memahami realitas sosial (2015:12-13). Pertama, memahami masyarakat sebagai sebuah sistem dari pada bagian antar individu. Kedua, kemunculan hubungan timbal balik antar bagian masyarakat. Ketiga setiap sistem selalu mengarah pada titik keseimbangan meskipun tidak pernah sempurna. Keempat, meski ketegangan dan konflik internal tetap terjadi dalam sistem masyarakat, tetapi sistem tetap selalu mengarah pada keseimbangan yang dituju melalui usahausaha penyesuaian. Kelima, perubahan dalam sistem terjadi secara gradual dan berkesinambungan. Keenam, terdapat tiga macam kemungkinan yang menjadi faktor perubahan: hadirnya penyesuaian dalam sistem yang berasal dari luar, pertumbuhan melalui diferensiasi struktural dan fungsional, hadirnya penemuan baru dalam masyarakat. Ketujuh, hadirnya konsesuskonsesus daklam masyarakat untuk mencapai kesepakatan nilai-nilai tertentu.

Menggunakan tujuh hakikat beserta empat ciri keilmuwan disiplin sosiologi yang ditopang oleh tujuh anggapan dasar perspektif fungsionalisme, yaitu gagasan Talcott Parsons tentang hubungan kendali antara struktur dan tindakan individu mendapatkan aktualisasinya. Hubungan kendali menempatkan struktur sebagai yang lebih dominan untuk mengatur dan memberikan batasan pada tindakan individu yang menggunakan empat kategori fungsi telaah struktur masyarakat. Aktualisasi perspektif fungsionalisme Talcott Parsons dirumuskan oleh Nasikun pada telaahnya tentang struktur masyarakat majemuk Indonesia, sistem kepartaian Indonesia dan persoalan integrasi nasional (2015:69).
Telaah perspektif fungsionalisme dari Selo Soemardjan dan Soerjono Soekanto memberikan landasan pemahaman bagi telaah Nasikun yang berujung pada pendefinisan struktur masyarakat Indonesia dan kebutuhan integrasi nasional yang diawali dengan menyatakan kebutuhan penerapan teori fungsionalisme Talcott Parsons. Nasikun beranjak dari klaimnya terhadap peristiwaperistiwa masa lalu yang dianggapnya bersifat destruktif, mulai dari peristiwa pemberontakan PKI tahun 1948, DI/TII, PRRI-Permesta, dan tentunya Gerakan 30 September 1965. Namun, Nasikun sekedar memaparkan bahwa deretan pemberontakan tersebut yang melemahkan salah satu dasar negara yang berguna menjaga kesatuan bangsa: Bhinneka Tunggal Ika, tanpa memberikan penjelasannya lebih jauh terkait latar belakang penyebab terjadinya peristiwa tersebut. Kebutuhan terhadap kembalinya persatuan tentu dekat dengan alasan legitimasi Soerjono Soekanto dan Ratih Lestari yang mendambakan jalan keluar dari rasa ketakutan dalam konsep Leviathan yang digunakannya.

Secara gamblang yang disasar oleh Nasikun adalah masa awal kemerdekaan Indonesia hingga periode Demokrasi Terpimpin. Berbagai data tentang konflik horizontal dan demonstrasi yang hadir dijadikan penanda sebagai bobroknya sistem pemerintahan pada tahun 1947 hingga 1967. Mendefinisikan kemajemukan masyarakat Indonesia setelah kemerdekaan yang tidak memiliki suatu landasan bersama. Serta menggambarkan struktur masyarakat Indonesia lewat sistem kepartaian hingga periode Demokrasi Terpimpin. Dua posisi yang melandasi pemahaman Nasikun 
Jurnal Pemikiran Sosiologi Volume 6 No.2 2019

Kritik Kuasa Mpu Tantular sebagai Ulayatisasi Ilmu Sosial Indonesia

Hartmantyo Pradigto Utomo dan Purwanto

adalah sikapnya untuk menyatakan anti pada penjajahan sekaligus anti pada gerakan Kiri di Indonesia (2015:75). Senyatanya, kedua posisi tersebut adalah strategi dari Amerika Serikat yang sudah dilancarkan semenjak tahun 1940 demi menguasai sumber daya Hindia Belanda secara total (Southwood \& Flanagan, 2013:75).

Nasikun berdalih bahwa kebobrokan tersebut adalah jalan menuju pembaruan sistem yang dicita-citakan untuk menemukan konsesus baru secara bersama oleh para penganut perspektif fungsionalisme. Sebuah cita-cita yang berusaha untuk menciptakan suatu masyarakat yang memiliki satu landasan bersama, tanpa adanya konflik, serta menjadi satu kesatuan yang utuh. Secara tersirat Nasikun menyatakan bahwa Orde Baru yang lahir setelah periode Demokrasi Terpimpin sebagai wujud penemuan baru bagi konsensus bersama dengan bersifat gradual.

Merunut dari logika yang dibangun oleh Soerjono Soekanto dan Selo Soemardjan, alasan yang dikemukakan Nasikun ditempatkan sebagai realitas yang mendasari pemahaman teori fungsionalisme Talcott Parsons. Meski dalam Setangkai Bunga Sosiologi dan Fungsionalisme dan Teori Konflik dalam Perkembangan Sosiologi alasan politis tersebut tidak muncul dan terkesan sebagai penjelasan yang murni tentang ilmu pengetahuan. Hingga sampai pada kesimpulan bahwa disiplin ilmu sosiologi yang sudah didefinisikan dekat dengan teori fungsionalisme yang berperan sebagai jalan keluar.

Usaha mewacanakan pemikiran Mpu Tantular sebagai diskursus alternatif dalam ilmu sosial Indonesia dilakukan dengan membongkar kecenderungan cara berpikir para ilmuwan sosial Orde Baru yang semata-mata hanya melihat realitas yang berada dipermukaan sesuai dengan empat ciri keilmuwan sosiologi: empiris, teoritis, kumulatif, dan nonetis. Juga ditopang dengan hakikat kelimuwan sosiologi yang berusaha untuk memamahi gejala dari realitas sosial, melakukan penilaian untuk menentukan kategorisasi, hingga memberlakukan pola-pola dan konsep-konsep yang diberlakukan secara universal. Kecenderungan cara berpikir tersebut justru jatuh dalam tradisi berpikir empirisisme klasik yang berusaha memahami realitas sosial hanya berdasarkan kenyataankenyataan dan indikator yang nampak secara indrawi semata. Kecederungan berpikir tersebut sangat berpotensi untuk menyederhanakan sebuah realitas sosial tanpa berusaha menelisik pada faktor-faktor kehadiranmya.

Salah satu bentuk penyederhanaan realitas sosial dijelaskan Nasikun dalam pendefinisian konsep struktur masyarakat Indonesia dan kebutuhan integrasi nasional yang ditujukan untuk melegitimasi rezim Orde Baru. Penyederhanaan tersebut terjadi ketika gagasan tersebut senyatanya cukup bertolak belakang dengan realitas yang terjadi. Dikarenakan rezim Orde Baru dalam praktiknya justru kerap menggunakan cara-cara kekerasan untuk mengantisipasi kehadiran dan perlawanan bagi pihak yang dianggap berseberangan cara pandang, terutama pihak-pihak kritis yang berada di sayap Kiri. Pemerintah Orde Baru mulai melakukan cara-cara kekerasan seperti propaganda dan teror (Southwood \& Flanagan, 2013:80). Jika propaganda diklasifikasikan dalam kekerasan yang tersamar dan tanpa wujud fisik, 


\section{Jurnal Pemikiran Sosiologi Volume 6 No.2 2019 \\ Kritik Kuasa Mpu Tantular sebagai Ulayatisasi Ilmu Sosial Indonesia \\ Hartmantyo Pradigto Utomo dan Purwanto}

maka teror merupakan bentuk kekerasan secara fisik.

Berbagai bentuk kekerasan yang dilakukan oleh rezim Orde Baru memiliki legitimasinya dari usaha propaganda yang berbasis pada fabrikasi narasi sejarah (Wood, 2013:14). Seperti yang dituju oleh Nasikun, Orde Baru terlahir dan berdiri kokoh dari propaganda sejarah kekacauan yang terjadi semasa awal kemerdekaan hingga Demokrasi Terpimpin. Bahwa sejarah yang ditempa untuk menyesuaikan kebutuhan kekuasaan merujuk pada persetujuan terhadap kebutuhan kemerdekaan, tetapi tidak untuk kepemimpinan Soekarno dan gerakan Kiri. Narasi sejarah rezim Orde Baru tertuang jelas dalam empat jilid buku 30 Tahun Indonesia Merdeka (Ir. Ginanjar Kartasasmita, 1986). Berikut juga berbagai narasi sejarah yang berusaha untuk menyingkirkan PKI sebagai lawan tanding kekuasaan rezim Orde Baru yang akhirnya dibukukan dalam lima jilid Bahaya Laten Komunisme di Indonesia (ABRI, 1995).

Kekerasan fisik yang berguna sebagai teror langsung dilakukan dengan melakukan pembantaian massal dan penghilangan paksa sedari akhir tahun 1965 hingga 1966 yang berguna untuk menciptakan keterkejutan dan ketakutan bagi seluruh masyarakat yang menjadikannya bungkam dalam waktu yang relatif panjang. Diberlakukannya hukuman penjara bagi para anggota PKI dan juga orang-orang yang berusaha melawan dengan tudingan sebagai simpatisan PKI tanpa adanya proses pengadilan.

Imbas dari pemenjaraan tersebut adalah munculnya stigma eks Tapol (tahanan politik) yang menyulitkan setiap korbannya dalam urusan birokrasi setelah selesainya masa penahanan. Terdapat juga perbudakan besar-besaran yang terjadi di pulau Buru sebagai salah satu tempat pembuangan para korban. Berikut juga terjadinya kekerasan seksual terhadap para korban perempuan yang dilakukan oleh para penjaga tahanan. Hingga bentuk-bentuk kekerasan seperti pengasingan bagi seluruh warga negara Indonesia yang sedang berada di negara-negara yang berhaluan Kiri (Klinken, 2017:268). Seluruh bentuk kekerasan diresmikan demi menekan dan mendapatkan kepatuhan serta meminimalisir perlawanan dari seluruh elemen masyarakat hingga akhirnya tunduk di bawah perintah rezim Orde Baru.

Posisi ilmu sosial Indonesia pada masa Orde Baru dapat dikategorikan sebagai yang 'buruk' dalam kategori aksiologi kritik kekuasaan Mpu Tantular. Dikarenakan terdapat dua konsekuensi fatal yang hadir dari ilmu sosial Indonesia. Pertama, konsekuensi dari legitimasi kebijakan dan kebutuhan rezim Orde Baru yang menjadikan hakikat pembunuhan dan kekerasan ratusan ribu manusia sebagai biaya imperatif dari proses kekuasaan dipahami sebagai normalitas dari proses transisi kekuasaan. Kedua, konsekuensi dari penggunaan paradigma fungsionalisme Talcott Parsons yang menjadikan orientalisme dan kebergantungan akademis sebagai sesuatu yang wajar dan diterima sebagai kanon reproduksi keilmuan yang terus menerus bergantung pada modernisme Amerika Serikat.

Berpijak pada penjabaran di atas, kritik kekuasaan dari gagasan Mpu Tantular dilancarkan pada dua sifat ilmu sosial Indonesia pada masa Orde 


\section{Jurnal Pemikiran Sosiologi Volume 6 No.2 2019 \\ Kritik Kuasa Mpu Tantular sebagai Ulayatisasi Ilmu Sosial Indonesia \\ Hartmantyo Pradigto Utomo dan Purwanto}

Baru: netral dan objektif. Relasi kuasa antara ilmu sosial dam rezim Orde Baru secara terang tidak dapat lagi mempertahankan klaim keilmuan yang netral dan seolah-olah tak berpihak pada posisi dan afiliasi politik apapun. Klaim netral gagal secara otomatis sedari kehadirannya di Indonesia karena kontradiksi dan determinasi rezim ekonomi politiklah yang justru melahirkan dan mengembangkan gagasan keilmuan sosial tersebut. Gugurnya klaim netral dalam kaidah keilmuan sosial turut secara langsung menggugurkan klaim objektif yang berusaha melegitimasi kajian-kajian ilmu sosial. Klaim objektif yang bertendensi menghadirkan cara pandang yang murni tanpa intervensi dalam pembacaan realitas sosial dengan sendirinya gagal karena upaya legitimasi yang ditujukan untuk membendung gagasan Marxisme dan komunisme di Indonesia dengan berpihak pada liberalisme modern Amerika Serikat.

Kontradiksi keilmuan sosial Indonesia pada Orde Baru membawa gagasan kritik kekuasaan Mpu Tantular pada basis ketidakmungkinan untuk melepaskan dan memisahkan paradigma teoritik secara subjektif pada bentuk-bantuk praxis keilmuan (Utomo, 2017). Karena pada hakikatnya, keilmuan selalu politis dan tak mungkin terlepas dari praktik-praktik yang bertujuan untuk melakukan koreksi dan intervensi pada kondisikondisi objektif dari realitas aktual. Oleh karena itu, Mpu Tantular memberikan posisi kepada upaya kritik sebagai bentuk ideal dari hakikat keilmuan.

\section{E. Kesimpulan}

Pemikiran Mpu Tantular mampu menghadirkan gagasan kritik yang relevan bagi ilmu sosial Indonesia. Gagasan kritik yang dilahirkan dari Kakawin Sutasoma diposisikan sebagai sebuah hakikat yang ideal dari sebuah keilmuan. Gagasan kritik tersebut dikonseptualisasikan sebagai kritik kekuasaan yang mampu membongkar relasi kuasa antara klaim keilmuan yang netral objektif sebagai bentuk legitimasi terhadap kekerasan dan biaya kemanusiaan sebagai hakikat utama kelahiran rezim kekuasaan Orde Baru. Oleh karena itu, dapat ditarik kesimpulan pertama bahwa pemikiran kritik Mpu Tantular mampu mendorong keterlekatan antara basis ilmu sosial dengan praktik yang mengarah pada bentuk-bentuk emansipatoris.

Gagasan kritik kekuasaan Mpu Tantular menjadi relevan bagi diskursus alternatif ilmu sosial Indonesia disebabkan oleh dua hal. Pertama, konteks asali dari Kakawin Sutasoma yang berasal dari zaman Kerajaan Majapahit yang mampu menjadi sumber pemikiran baru melalui metode hermeneutika yang menghasilkan konsep ontologi, epistemologi, dan aksiologi secara mandiri. Kedua mampu menghadirkan dialog kritis dengan tradisi ilmu sosial modern Amerika melalui orientasi ilmu sosial otonom yang berpijak pada sejarah ulayat kontekstual tanpa bergantung sepenuhnya pada kanon ilmu sosial Barat.

Terdapat dua batasan dari penelitian ini yang hadir ketika gagasan kritik kekuasaan Mpu Tantular masih berposisi sebagai kajian awal yang menjadi pemantik bagi upaya melawan orientalisme dan kebergantungan akademis. Batasan pertama, persoalan horizon penafsir dalam kerangka 
Jurnal Pemikiran Sosiologi Volume 6 No.2 2019

Kritik Kuasa Mpu Tantular sebagai Ulayatisasi Ilmu Sosial Indonesia

Hartmantyo Pradigto Utomo dan Purwanto

hermenutika yang masih terpapar penuh oleh kanon ilmu sosial Barat. Menjadi naif ketika keseluruhan penafsiran teks Kakawin Sutasoma hadir tanpa adanya endapan pengetahuan dari ilmu sosial Barat. Batasan kedua, dominasi struktur ilmu sosial Indonesia hari ini yang belum membuka peluang besar bagi kajian-kajian yang berfokus pada wacana dekolonialisasi. Oleh karena itu, penelitian ini belum mampu menggedor dominasi struktur keilmuan yang sudah mapan selama puluhan tahun tanpa hadirnya riset lanjutan maupun kolaborasi yang bertujuan sebagai agenda intelektual yang bersifat emansipatoris.

\section{Daftar Pustaka}

Sumber Buku dan Jurnal

Abdullah, T. 1983. "Ilmu Sosial dan Peranannya di Indonesia". Jurnal PRISMA, Teori Kritik Sosial. No.6, Juni., LP3ES.

Abdullah, T. 1997. "Pelaksanaan Masa Lampau dan Arah Masa Depan; Negara dan Ilmu Sosial di Indonesia". Dalam N. S. Nordholt, \& L. Visser. Ilmu Sosial di Asia Tenggara; Dari Partikularisme ke Universalime .Jakarta: LP3ES: 51-70

ABRI. 1995. Bahaya Laten Komunisme di Indonesia; Jilid I-V. Jakarta: Markas Besar Angkatan Bersenjata Republik Indonesia dan Pusat Sejarah dan Tradisi ABRI.

Alatas, S. F. 2010. Diskursus Alternatif dalam Ilmu Sosial Asia. Yogyakarta: Mizan.

Alatas, S. F., dan Sinha, V. 2017. Sociological Theory Beyond the Canon. London : Palgrave Macmillan.

Boeke, J. H. 1983. Prakapitalisme di Asia. Jakarta: Sinar Harapan.
Dhakidae, D. 2003. Cendekiawan dan Kekuasaan dalam Negara Orde Baru. Jakarta: Gramedia Pustaka Utama.

Fansuri, H. 2015. Sosiologi Indonesia; Diskursus kekuasaan dan Reproduksi Pengetahuan. Jakarta: LP3ES.

Hardiman, F. B. 2015. Seni Memahami; Hermeneutik dari Schleiermacher sampai Derrida. Yogyakarta: Kanisius.

Haryatmoko. 2016. Membongkar Rezim Kepastian. Yogyakarta: Kanisius.

Heryanto, A. 2006. "Kiblat dan Beban Ideologi Ilmu Sosial Indonesia", dalam V. R. Hadiz, \& D. Dhakidae (Eds), Ilmu Sosial dan Kekuasaan di Indonesia. Jakarta: Equinox Publishing Indonesia: 63-98

Hurgronje, C. S. 1994. "Politik Islam Belanda", dalam C. S. Hurgronje, Kumpulan Karangan Snouck Hurgronje jilid $X$. Jakarta: INIS: 55-60

Ir. Ginanjar Kartasasmita, d. 1986. 30 Tahun Indonesia Merdeka; Jilid I-IV. Jakarta: P.T. Citra Lamtoro Gung Persada.

Kalupahana, D. J. 1986. Filsafat Buddha; Sebuah Analisis Historis. Jakarta: Erlangga.

Kleden, I. 1988. Sikap Ilmiah dan Kritik Kebudayaan. Jakarta: LP3ES.

Kleden, I. 1997. "Ilmu Sosial di Indonesia; Tindakan dan Refleksi dalam Perspektif Asia Tenggara", dalam N. S. Nordholt, \& L. Visser (Eds), Ilmu Sosial di Asia Tenggara; Dari Partikularisme ke Universalime. Jakarta: LP3ES: 10-40

Klinken, H. v. 2017. Final Report of The IPT 1965; Laporan Akhir Pengadilan Rakyat Internasional 1965. Bandung: Ultimus.

Lombard, D. 1996. Nusa Jawa: Silang Budaya; Bagian II: Jaringan Asia. Jakarta: Gramedia Pustaka Utama dan Forum Jakarta-Paris.

Mastuti, D. W., dan Bramantyo, H. 2009. "Sekilas Tentang Sutasoma", dalam M. Tantular, 
Jurnal Pemikiran Sosiologi Volume 6 No.2 2019

Kritik Kuasa Mpu Tantular sebagai Ulayatisasi Ilmu Sosial Indonesia

Hartmantyo Pradigto Utomo dan Purwanto

Kakawin Sutasoma. Depok: Komunitas Bambu: xiv.

Nasikun. 2015. Sistem Sosial Indonesia. Yogyakarta: Ombak.

Rahadianto, O., dan Samuel, H. 2013. "The Many Faces of Indonesia: Knowledge Production and Power Relations". Journal Asian Social Science Vol. 9 (13): 289-298.

Ricoeur, P. 1976. Theroy of Interpretation: Discourse and the Surplus of Meaning. Texas: Texas Christian University Press.

Riyanto, G. 2011. "Selo Soemardjan Sang Penerjemah: Subjektivitas dalam Asal-Usul Cara Berpikir Sosiologis di Indonesia". Jurnal Antropologi Indonesia Vol. 32(2): 153-172.

Robinson, R. 2012. Soeharto dan Bangkitnya Kapitalisme Indonesia. Depok: Komunitas Bambu.

Samuel, H. 1999. The Development of Sociology in Indonesia: The Production of Knowledge, State Formation, and Economic Change. Disertation: Swinburne University og Technology.

Samuel, H. 2010. Genealogi Kekuasaan Ilmu Sosial Indonesia; Dari Kolonialisme Belanda hingga Modernisme Amerika. Depok: Kepik Ungu.

Santoso, S. 1975. Sutasoma; A Study In Javanese Wajrayana. Disertation: Australian National University dan International Academy of Indian Culture.

Soedjatmoko. 1983. "Etik dalam Perumusan Strategi Penelitian Ilmu-Ilmu Sosial". Jurnal PRISMA, Teori Kritik Sosial. No.6(Juni), LP3ES.

Soekanto, S. 1982. Sosiologi Suatu Pengantar. Jakarta: Rajawali Press.

Soekanto, S., dan Lestarini, R. 1988. Fungsionalisme dan Teori Konflik dalam Perkembangan Sosiologi. Jakarta: Sinar Grafika.

Soemardjan, S. 1984. "Ilmu itu Netral dan Ilmuwan Harus Objektif", dalam A. E. Priyono, \& A. 0.
Saleh (Eds), Krisis Ilmu Sosial dalam Pembangunan Di Dunia Ketiga. Yogyakarta: PLP2M.

Southwood, J., dan Flanagan, P. 2013. Teror Orde Baru; Penyelewengan Hukum dan Propaganda 1965-1981. Depok: Komunitas Bambu.

Supomo. 2000. "Tantular dan Karyanya". Dalam J. Kristanto, 1000 Tahun Nusantara. Jakarta: Kompas: 501

Tantular, M. 2009. Kakawin Sutasoma. Depok: Komunitas Bambu.

Tjondronegoro, S. M. 1983. "Penelitian Ilmu Sosial dan Penentu Kebijakan". Jurnal PRISMA, Teori Kritik Sosial. No.6 (Juni) LP3ES.

Wood, M. 2013. Sejarah Resmi Indonesia Modern; Versi Orde Baru dan Penantangnya. Yogyakarta: Ombak.

Yamin, M. 1975. Gadjah Mada. Jakarta: Balai Pustaka.

Zoetmolder, P. J., dan Robson, S. o. 2006. Kamus Jawa Kuno Indonesia. Jakarta: Gramedia dan KITLV.

Sumber Skripsi (Tidak dipublikasikan)

Utomo, H. P. 2017. Kuasa/Kritik; Kajian Awal Nalar Kritik Kekuasaan dan Gagasan Emansipasi Mpu Tantular Sebagai Ulayatisasi Pemikiran Ilmu Sosial Indonesia. Skripsi: Departemen Sosiologi. Universitas Gadjah Mada. 